10 years ESJ

Special edition

\title{
Improving the Regulation of Joint Rights in Civil Law
}

\author{
Ekaterine Nandoshvili, PhD Student
}

Grigol Robakidze University, Tbilisi, Georgia

Doi: 10.19044/esj.2021.v17n30p69

Submitted: 05 March 2021

Accepted: 23 August 2021

Published: 10 September 2021
Copyright 2021 Author(s)

Under Creative Commons BY-NC-ND

4.0 OPEN ACCESS

Cite As:

Nandoshvili E. (2021). Improving the Regulation of Joint Rights in Civil Law. European Scientific Journal, ESJ, 17 (30), 69. https://doi.org/10.19044/esj.2021.v17n30p69

\section{Abstract}

This paper focuses on analyzing the norms regulating joint rights, presents their shortcomings, and criticizes the misconceptions expressed in the legal literature about the types of common property, joint rights, and coownership. The paper considers the incompleteness of the provisions regulating the legal consequences of the abolition of joint rights as a serious shortcoming of the Civil Code of Georgia. A novelty is a mechanism proposed in this paper, and it is possible to assign the entire property to one of the participants in case of abolition of joint right, in exchange for compensation for the shareholder who requests the abolition of joint right and the allocation of the amount. The objective of the paper is to analyze certain aspects of the regulation of joint rights, which, together with the theoretical, have the practical importance that will contribute to a correct understanding of a number of issues and the correct qualification of the rights and obligations of participants of the legally binding relationship, rising on the basis of joint rights. To achieve this objective, logical and systematic analysis of norms as well as comparative-legal methods are used. Using these methods, it is possible to determine the strengths and weaknesses of the norms of Georgian law or to better understand their content, to identify gaps in the legislation in court practice, as well as to develop proposals and recommendations for the improvement of norms and practice. The problems are analyzed using the examples of Georgian, German, and Swiss civil law. The common features and shortcomings were identified between the Georgian and German models regarding the issue of the consequences of the abolition of joint rights. The Swiss model appears to be the most perfect and effective model among the named ones. The study found that neither in practice nor under the law is a 
shareholder allowed to sell the joint item in an auction by redeeming the shares of other owners. The extinction of this opportunity for the owner reduces the essence of ownership. In order to extend the guarantees for full protection of the property rights, a view is proposed on the need to develop an approach, similar to the Swiss model, and the implementation should be ensured by case law before the law is changed.

Keywords: Joint civil rights, Shared, Common Property, Share

\section{Introduction}

Joint rights are one type of common property. The existence of joint rights is an indicator of the origin of shared common ownership. The Georgian civil law was already familiar with the share ownership. However, with the transition to a market economy, the ownership rights in general, and common share ownership in particular, acquired a new content and fell primarily within the scope of the contractual freedom, which was regulated by dispositional norms. The rapprochement of Georgian law with the German law also added the new content to the above-mentioned institute. It was under the influence of German law that the provisions of Articles 953-968 of the Civil Code of Georgia arose, which almost literally repeat the provisions of Section 17 of the German Civil Code (\$741-758) (Kropholler, 2014, p.561-564). Therefore, the provisions of the Georgian Civil Code have the same shortcomings as the shortcomings of this institution in German law. Also, provisions governing the common property are defined not only by the Civil Code. For example, the right of common ownership between apartment owners is regulated by the Law of Georgia "On partnership of apartment owners", which was adopted on July 11, 2007.

The purpose of this paper is not to analyze the types of common property and all the provisions governing them. The aim of the paper is to analyze the effectiveness of the norms reflected in the private part of the Civil Code of Georgia, in the first chapter of its second section, using the comparative method. The purpose of the analysis of these norms is to identify gaps in both legislation and practice and to develop proposals for improving existing regulations and practices. The issues analyzed in the paper did not become the subject of discussion in the Georgian legal literature. All of the above makes the problem urgent.

\section{Common Property Types and Terminology}

Joint rights are one type of common property. The provision is reasonable, and "the nature of common property is most reflected in shared rights." (Zoidze 1999, p.76). The institution of joint rights is reflected in the part of the Civil Code that combines several types of legally binding 
relationships. Therefore, due to shared rights, legally binding relations will rise between the subjects of this right. There is no doubt that the existence of a joint right implies the existence of a legal right of common ownership over a particular property. As it is well known, there are two types of common property. These are co-ownership and share ownership (Article 173 of the Civil Code of Georgia).

In this regard, the first question arises: if joint rights relate to the common property, and one of the types of common property is co-owned property, does the co-owned property and shared rights have categories with similar content? This question must be answered in the negative. This is because co-ownership means only one type of common property rising under the law. Therefore, it is difficult to agree with the statement of Professor Zurab Chechelashvili, who stated that the criterion of co-ownership and share ownership is known when the share of co-owners in the item/property is specified. For example, if a share is not specified, this should be considered as the existence of joint ownership (Chechelashvili, 2009, p.105). Therefore, according to Article 173 of the Civil Code, common property will rise on the basis of law or transaction. There is a rule that common property rises on the basis of law or transaction, which applies equally to both types of common property - co-ownership and share ownership. However, in reality, a different approach to the basis of common property is required. In particular, coownership rises only by the force of law. The share is based on both the law and the transaction. The Georgian law provides for only one case when the right of property rises by force of law. Specifically, this concerns the joint property of the spouses. This is why it is difficult to accept the example cited in the Georgian legal literature, whereby the common joint ownership will be a bicycle bought by two persons together, a common wall or common parts of the building such as a staircase (Zarandia, 2019, p.235). The example of a real estate can best be seen in the case of co-ownership. Regardless of the registration of one of the spouses as the owner of the immovable item, the other spouse is also considered the owner by the force of law. This means the co-ownership in the legal right of ownership. In the case of co-ownership, the person is entitled to an imaginary arithmetic part of the property. This means that the individual has a share in the whole property and not in a specific part of it (Wolf \& Wellenhofer, 2016). Therefore, the position of Professor Tamar Chitoshvili is wrong, who shares the opinion that the property of one of the spouses registered as the owner of the real estate in the public register ... is also the co-ownership of the other spouse, even if the second spouse is not 
registered as an owner in the public registry. Thus, the public registry loses its function (Chitoshvili, 2006, p. 67) ${ }^{1}$.

In regards to the common rights, the analysis of the legal norms regulating them clearly shows that it concerns the shareholders, shares, share management rules, and more. Therefore, it concerns the share ownership, which is the second type of common property and this cannot be equated with co-ownership. For the purpose of comparison, the German Civil Code recognizes three forms of co-ownership. This includes not only the joint property of the spouses (Article 1416 of the German Civil Code), but also the partnership type property (in Georgian law such as the joint liability company and the limited partnership, as well as the entrepreneur partnership which are included in the joint property regime. Article 930 of the Civil Code of Georgia) (Articles 718 and 719 of the German Civil Code), and common property of the heirs (Article 2032 of the German Civil Code) (Wolf \& Wellenpofer, 2016, p.25-26). Furthermore, the German order coincides with the Georgian reality in only one part in order to determine the property regime of the spouses. However, the other parts of the regulation are different.

Summarizing the results of this part of the study allows the following conclusions to be drawn: the term "joint right" is not equivalent to "shared ownership". The joint right is an indicator of the share ownership, while coownership is a phenomenon different from the share ownership. In order to ensure the unity of terms, it is advisable to use the category of "property" or the concept of share ownership instead of the "common item" specified in the norms governing the joint rights.

\section{Sphere of Regulation of Joint Rights}

According to Article 953 of the Civil Code, unless otherwise provided by a special law, the rules of the first chapter of the second section of the Civil Code shall apply to joint rights. It is interesting to note which special law this norm implies. Furthermore, the issues of common property and determination of share in common property are also regulated by the Law of Georgia on "Partnership of apartment Owners". Nevertheless, it should be noted that this law introduces the concept and mode of special ownership. The origin of special property has its own history in German law and is linked to the problem of providing housing to the population of post-World War II war-torn Germany. As it is known, German law, as well as Georgian law, recognizes the principle of considering land and buildings. According to Professor Besarion Zoidze's reasonable opinion, the old tradition of building stone whitewashed houses in Georgia is a sign that the concept of real estate on

\footnotetext{
${ }^{1}$ And the position which is shared by Professor Tamar Chitoshvili is expressed by notary Otar Zoidze in the Collection of Georgian Private Law (2004). Book I (p. 27).
} 
buildings should have been spread in our country as well (Zoidze, 1999, p.25). According to Professor Lado Chanturia's study of real estate ownership, the principle of unity of the land and buildings proved unsuitable for the post-war reality.

In general, multi-apartment houses are not distinctive for Europe. Therefore, it has become an inevitable necessity to provide housing for the population. The problem is the principle of unity of land ownership and the building built on the land. This building is the property of the landowner even when it is built by someone else. Therefore, the right of ownership of a land plot does not only refer to the land, but also the buildings on that plot, including residential houses (Chanturia, 1994, p.247-251). Therefore, the right of special property was introduced, which means that in the multi-apartment house/building, the person owns both individual ownership of the apartment and a share in the common ownership of the land. However, the amount of this is determined in proportion to the individual ownership. Nonetheless, the existence of a share in the common property does not mean that, like joint rights, the owner of the apartment can separate the share in kind or request the sale of the commonly owned land at auction. The land on which the multiapartment building is built cannot be subject to the legal regime established by joint rights, and the apartment/building area may be the subject of joint right.

Since the shared item has been mentioned, it is important to find out what the law means in the shared item. The legislator was obliged to defend its own requirement, which is reflected in Article 1519 of the Civil Code (unity of concepts and terms), and to use the term "Property" instead of the term "Item". This is because the concept of property is broader and includes intangible property. The term "Item" is more equivalent to a thing, while a shared right may exist for both the item and the intangible property or property in general. Thus, the term "shared subject" does not fully reflect the object of shared ownership.

\section{Ways and Consequences of Abolition of Joint Rights}

The key issue is the consequences of the abolition of joint rights.This issue is incompletely regulated by the Civil Code of Georgia. In particular, only two options specifying such results are proposed by the legislator. The case law also highlights that the Civil Code of Georgia recognizes two possibilities for abolition of joint right, abolition of joint right by division in kind (Article 963), and abolition of joint right through the sale of a common item (Article 964) (Decision of the Supreme Court of Georgia on the case NAS-1148-1094-2014, March 19, 2015). Therefore, with the exception of other options, both the law and the practice, based on the law, create a problem for the co-owner. 
Furthermore, joint right is revoked in both cases Nevertheless the use of any of the two consequences of the law accompanying the abolition of joint right to the share depends on the possibility of separation of the item in kind. This is done so that the value of the item obtained as a result of the separation does not decrease. In accordance with the above-mentioned, if separation in kind is possible without reducing the value of the item, then joint right will be abolished and the property will be really divided. Real division which refers to the separation of the real share means the transformation of property into individual property. Therefore, it is difficult to come to terms with the opinion formed in the Georgian legal literature, whereby the real share is considered where there is talk of common property (Shotadze, 2014, p.128). Thus, if this is not possible (which should be determined by the conclusion of the expertise), then the abolition of joint right will have a legal consequence, i.e., the sale of the property at auction and the distribution of the proceeds among the shareholders (holders of joint rights) in proportion to their shares.

In this regard, it is important to find out if it is possible to use the third option. Is it possible for one of the shareholders to be given the amount/fair price corresponding to the market value of his/her share, and the other shareholder given the entire property in kind? The legislator, however, does not say anything about this possibility. More so, the shareholders of the joint right have the right to voluntarily separate the property on the basis of an agreement between them. Property will also be separated in Court based on the expert's report. This happens if a positive answer is given to the question of the possibility of separating the property without reducing the value. Therefore, there is a clear possibility for a particular party to claim the property/share of the other party in exchange for compensation in case of indivisible property by force or court. On this note, this third option should not be excluded. However, it is important to determine the cases where there may be a right to receive a share in exchange for compensation. This right is not unconditional and may not apply in all cases.

Certain factors must be considered in order to resolve this issue correctly. The inseparable nature of property inevitably creates the need to sell property. The parties often fail to reach an agreement on this issue, which leads to a lawsuit being filed by the plaintiff who is interested in selling the property and receiving the money. Accordingly, a shareholder who is not interested in selling the property may file a counterclaim and claim ownership of the original plaintiff's share in exchange for the share compensation. Such a resolution of the issue does not infringe on the rights of the original plaintiff, since its purpose is exactly to obtain money as a result of the sale of the property. Accordingly, he/she will receive a fair price commensurate with the market value of his/her shares. Consequently, it is inadmissible to request the forced sale of a share or to be declared the owner of the share in exchange of 
compensation if the shareholder to whom the claim for share ownership/the certificate of ownership of the share has been filed or has not filed a lawsuit against the abolition of joint right and the sale of the property at auction. Only in the case of such a lawsuit can the defendant sue that he/she does not want to sell the property since the plaintiff's purpose is to obtain money and to request custody attribution of the property in exchange for payment.

Also, it is important to take note of the regulation established by the Swiss Civil Code in this regard. The Swiss Civil Code brings together the norms governing both joint rights and co-ownership, in the fourth part of the Code, which deals with Property Law. Article 651 of the mentioned Code names direct sale as the third way of carrying out the abolition. This is in line with the division of property and the abolition of the common property through auction. According to the rule of this norm, it is also possible to transfer the whole thing to several co-owners on the condition of redemption from the other co-owners and to cancel the common property in this way as well.

Finally, the abolition of joint right raises the issue of debt settlement. Article 965 of the Civil Code of Georgia allows the shareholder to demand payment of a debt from a common item on which joint rights are to be abolished. Regarding this, the basis of this request involves both joint and several liability rising under Article 600 of the Civil Code. Article 600 is one of the norms regulating the lease relationship and it has nothing to do with joint and several obligations. Unfortunately, this misunderstanding has not been rectified and Article 965 has not been amended until today. Thus, Article 965, instead of Article 600, should refer to the norms governing joint and several liabilities.

\section{Conclusion}

The analysis of the results of each part of the study revealed important problems such as the terminology in the norms governing common property rights which needs to be improved. The confusion of terms leads to formation of the erroneous approaches to both types of common property and the subject of joint rights. The scope of the regulation of joint right should not be confused with the regime of apartment ownership in multi-apartment buildings. Ways and consequences of the abolition of joint right also require expansion. Unfortunately, the case law does not stand at the proper level. The abolition of joint right in practice is also considered possible in only two ways, which is a fundamentally wrong approach. In the case of abolition of joint right, it should not be ruled out that in exchange for compensation of the share, the shareholder who does not want to sell the property and receive money in exchange for ownership of it should be recognized as the owner. However, this mechanism should only be used before legislative changes are made, which should unconditionally give the shareholder the right to redeem the 
shares and avoid the auction if any of the shareholders files a lawsuit to abolish joint right and sell the property at auction. Clearly, this concerns the indivisible items. Instead of the shared item, the concept of the property in the share ownership should be provided by law. Article 965 of the Civil Code of Georgia, which is a reference norm to Article 600, should be amended. Therefore, instead of Article 600, reference should be made to the norms regulating joint and several liabilities.

\section{References:}

1. BGB (2019). German Civil Code, Second Edited Edition, Tbilisi.

2. Chanturia L. (1994). Real Estate Property, Tbilisi University Press, Tbilisi.

3. Chanturia L. (1997). Introduction to the General Part of the Civil Part of Georgia, Publishing House "SAMARTALI", Tbilisi.

4. Chitoshvili T. (2006). Basic Legal Aspects of the Origin of Real Estate Ownership, Publishing House MERIDIANI, Tbilisi.

5. Collection of Georgian Law (2004). Book One.

6. Commentary on the Civil Code (2018). Book II, Art. 147 - 315, Tbilisi.

7. Dzamukashvili D. (2017). Property Law, Grigol Robakidze University Publishing House, Tbilisi.

8. Jauernig - BGB, Bürgerliches Gesetzbuch Kommentar (2002). 10.Auflage, Verlag C.H.Beck, München.

9. Kropholler J. (2014). German Civil Code - Study Commentary, the 13th revised edition, Tbilisi.

10. Muthorst O. (2019). Fundamentals of Jurisprudence, Method Concept - System, Tbilisi.

11. Shotadze T. (2014). Property Law, Meridian Publishing House, Tbilisi.

12. Swiss Civil Code (2018). stated on January 1, 2017, Tbilisi.

13. Wolf M. and Wellenhofer M. (2016). Sachenrecht, München.Zurab Chechelashvili (2009). Property Law, Tbilisi.

14. Wolf M. and Wellenpofer M. (2016). Property Law, the 29th Edition, Publisher LEPL " Notary Chamber of Georgia".

15. Zarandia T. (2019). Property Law, Tbilisi.

16. Zoidze B. (1999). Property Law, Publishing House "UPLEBA", Tbilisi. 